\title{
Dyskurs(y) posthumanizmu w kontekście współczesnej komunikacji
}

\author{
Post-humanism discourse(s) \\ in the context of contemporary communication
}

\author{
Artur Rejter \\ Wydział Filologiczny, Uniwersytet Śląski w Katowicach, \\ pl. Sejmu Śląskiego 1, 40-032 Katowice, Polska; \\ e-mail: artur.rejter@op.pl
}

\begin{abstract}
Abstrakt
Przeprowadzona analiza tekstów reprezentujących dyskurs posthumanizmu wykazała, że jest to dyskurs o charakterze ideologicznym, o kluczowej roli komponentu tematycznego. Charakterystyczna dla tego dyskursu jest także leksyka specjalna, neosemantyczne struktury nieciągłe oraz pytania jako element dynamizujący. Punktem odniesienia dla dyskursu posthumanizmu jest tradycyjny - antropocentryczny - porządek rzeczywistości, co poświadcza specyficzny obraz świata akcentujący równość wszelkich gatunków żywych i bytów transhumanistycznych. Dyskurs posthumanizmu wzbogaca współczesną przestrzeń komunikacyjną, poszerza kategorię podmiotu i reinterpretuje pojęcie kultury komunikacji.
\end{abstract}

Słowa kluczowe: dyskurs; posthumanizm; animal studies; stylistyka; lingwistyka tekstu.

\begin{abstract}
An analysis of texts representing the post-humanism discourse(s) has indicated that the discourse is an ideological one with the key role of a thematic component. Specialist lexis and neo-semantic discontinuous terms and expressions are of importance here together with questions as an element of added dynamics. The point of reference for the post-humanism discourse is the traditional, anthropocentric world order as confirmed by a specific picture of the world emphasizing the equality of all living species and trans-human entities. The post-humanism discourse enriches contemporary communication, extends the subject category and re-interprets the notion of communication culture.
\end{abstract}

Keywords: discourse; post-humanism; animal studies; stylistics; text linguistics.

Dyskurs ${ }^{1}$ jest dziś pojęciem często stosowanym, pojemnym i wieloznacznym. Poziomów, na których dyskurs może być rozpatrywany, wyróżnia się kilka. Boże-

${ }^{1}$ Definiowanie pojęcia dyskursu zajmuje badaczy od dawna, dyskurs ujmuje się jako swoisty zbiór wyznaczników szeroko rozumianego kontekstu komunikatu (van Dijk 2001), jako odpowiednik tekstu, konkretnego komunikatu (Żydek-Bednarczuk 2005), ustabilizowaną konwencję społeczno-kulturowo-komunikacyjną (Grzmil-Tylutki 2007), normę i strategię użytą w procesie tworzenia tekstu i wypowiedzi (Labocha 2008), nadrzędny wobec stylu, gatunku i tekstu wzorzec zdarzenia 
na Witosz wskazuje ich siedem, są to, upraszczając, poziomy: tekstowy, idiolektalny, gatunkowy, tematyczny, ideologiczny, instytucjonalno-wspólnotowy oraz kulturowy (2009: 58). Badaczka przyjmuje koncepcję niehierarchiczną dyskursu, nie sytuuje go więc ponad gatunkiem, widząc w nim raczej odrębny, komplementarny obszar komunikacji, szczególnie waloryzujący perspektywę interpretacji i kontekstualizację (Witosz 2009: 74-75). Takie założenie pozostaje w zgodzie ze współczesnym kształtem komunikacji, wymykającej się jednoznacznym kategoryzacjom, a nawet typologiom - stylistycznym czy generycznym.

Dyskursowa kontekstualizacja komunikacji prowadzi, prócz dyskusji nad wyznacznikami definicyjnymi dyskursu, do namysłu nad poszczególnymi jego aktualizacjami. Pojawianie się nowych dyskursów należy uznać za jeden z czynników dynamizujących komunikację, poszerzających obszar obcowania jej podmiotów, a także wzbogacających wymiar epistemologiczny współczesności. Jednym z takich dyskursów jest z pewnością dyskurs posthumanizmu. Zakłada on zmianę w hierarchii podmiotów, przewartościowanie porządku, wydawałoby się nienaruszalnego, świata, którego centrum stanowił człowiek.

Posthumanistyczna tradycja odrzuca tezę podziału uniwersum na świat Natury i świat Człowieka, jako umowny, sztuczny, niefunkcjonalny i bezzasadny. W świetle najnowszych odkryć nauki paradygmat o zwierzęciu, któremu odmawiano zdolności do świadomego odczuwania bólu, myślenia, (samo)świadomości, nie ma już racji bytu i nie może być dłużej bezkrytycznie akceptowany. Człowiek opuścił homocentryczny piedestał wyższości nad innymi bytami organicznymi (biocentryzm, ekocentryzm, zoocentryzm) i nieorganicznymi (transhumanizm), by zająć równorzędne z nimi miejsce. [...] Posthumanizm pyta o relację człowieka do bytów technicznych (maszyn, szczególnie robotów i cyborgów, androidów), a więc wychodzi poza ludzką perspektywę, a jednocześnie dowartościowuje inne istoty i »istoty« (nadaje status podmiotu zwierzętom i robotom z uwagi na ich coraz bardziej dostrzegalne podobieństwo do ludzi) oraz zastanawia się, jak określić człowieka, który pod wpływem różnych biotechnologii informatyczno-medycznych przestaje być wyłącznie tworem biologicznym i kulturowym, stając się w większym lub mniejszym stopniu bytem sztucznym/ technicznym, bytem wspomaganym. Posthumanizm proponuje kult tego wszystkiego, co następuje po przekroczeniu granic człowieczych cech/człowieczeństwa (Tymieniecka-Suchanek 2014: 9-10).

To syntetyczne przedstawienie cech dyskursu posthumanizmu skłania do zaliczenia go do dwóch poziomów w typologii refleksji nad dyskursem: tematycznego oraz - może przede wszystkim - ideologicznego ${ }^{2}$. Tematem wiodącym jest tutaj człowiek, jego podmiotowość, a głównie jego relacja do innych podmiotów. O specyfice decyduje założona polemika z utrwalonym w kulturze porządkiem,

komunikacyjnego i sposób jego realizacji (Wojtak 2011) czy wreszcie - jako model kształtowania tekstu niebędący w relacji hierarchicznej wobec modelu gatunkowego (Witosz 2009). Por. też różne ujęcia dyskursu w: Witosz red. w druku.

${ }^{2} \mathrm{O}$ innych poziomach, na których dyskurs może być rozpatrywany por. Witosz 2009: 58. 
który określa się mianem Wielkiego Łańcucha Bytu (Krzeszowski 1999: 34), wyznaczającym hierarchię wartości, schematycznie ujętym następująco:

\section{BÓG \\ LUDZIE \\ ZWIERZĘTA \\ ROŚLINY \\ BYTY NIEORGANICZNE}

Idea posthumanizmu znosi jednoznaczną hierarchizację aksjologiczną, a tym samym niweluje wzajemną zależność przedstawicieli poziomów położonych niżej niż ludzie, nadając im rangę równouprawnionych z człowiekiem podmiotów.

Aspekt ideologiczny dyskursu natomiast manifestuje się w warstwie postulatywnej, zmierzającej do wzbogacenia zbioru podmiotów równouprawnionych, a tym samym polega na polemice z zastanym, esencjonalistycznym porządkiem świata, próbuje go reinterpretować, a nawet burzyć. Proporcje między wymiarem tematycznym a ideologicznym dyskursu zależne będą od kontekstu jego aktualizacji, na przykład stylu czy gatunku, jaki reprezentuje. Inaczej bowiem sytuacja przedstawia się w sferze komunikacji naukowej, inaczej natomiast - w wypadku tekstów popularnonaukowych, agitacyjnych, publicystycznych, poradnikowych itd. Z uwagi na takie zróżnicowanie aktualizacji dyskursu posthumanizmu i słabe jego rozpoznanie na poziomie metarefleksji, także językoznawczej, można stosować na jego określenie formę liczby mnogiej: dyskursy posthumanizmu³

Można postrzegać dyskurs posthumanizmu w kategoriach relatywizmu rozumianego jako jeden z wyznaczników współczesnej kultury, przy czym warto zaakcentować neutralność tego pojęcia. Relatywizm bowiem nie musi być interpretowany wyłącznie w perspektywie krytycznej, jednoznacznie negatywnej. Jak zauważają badacze:

obawa przed relatywizmem opiera się na wątpliwym przekonaniu, że wielość opisów, teorii, obserwacji, punktów widzenia, schematów pojęciowych jest niczym nieograniczona i że jest nam całkowicie dostępna. W strachu tym ukrywa się przeświadczenie, że czy jako filozofowie, czy jako mieszkańcy współczesnego świata mamy do czynienia z ogromną ilością informacji na każdy temat i o każdym dowolnym elemencie świata, co powoduje, że nie bardzo wiemy, jak sprawdzić, która z owych informacji jest wiarygodna i prawdziwa. Sugeruje to, że jak pasywne i bezwolne podmioty poznające przyjmujemy gotowe już dane w ilości, której nie jesteśmy w stanie poznawczo ogarnąć. Będąc zwolennikiem względności, staram się pokazać, że ten obraz jest fałszywy. Aby jakaś informacja, opis, obserwacja, opinia mogły zostać sformułowane i przekazane w ustabilizowanej formie, musi zostać wykonana ciężka praca uwzględnienia związanych z nią zależności, wzięcia pod uwagę łańcucha relacji, które prowadzą do jej ukonstytuowania na rozmaitych poziomach (w teorii, w społeczeństwie,

${ }^{3}$ Dla przejrzystości wywodu w artykule stosować będę formę liczby pojedynczej. 
w rzeczach). Nie mamy tutaj, jak widać, do czynienia z dowolnością niczym nieograniczoną. Przynajmniej w tym sensie strach przed relatywizmem nie jest uzasadniony (Derra 2010: 22) .

Celem niniejszego studium jest przedstawienie - z konieczności sygnalne wyznaczników dyskursu posthumanizmu jako nowego fenomenu natury komunikacyjnej. Materiał badawczy jest zróżnicowany, obejmuje teksty reprezentujące różne style funkcjonalne i gatunki wypowiedzi, są wśród nich monografie i artykuły naukowe, książki popularnonaukowe, poradniki czy wydawnictwa o charakterze wspomnieniowym, autobiograficznym. Łączy je tematyka szeroko pojętego posthumanizmu oraz zauważalne zaangażowanie społeczne bądź ideologiczne ${ }^{5}$.

Teksty reprezentujące dyskurs posthumanizmu można rozpoznać już po tytule:

Po człowieku (BP), Prawa zwierząt. Bardzo krótkie wprowadzenie (GP), Manifest zwierząt (BM), Manifest cyborgów (HM), Człowiek w relacji do zwierzat, roślin i maszyn w kulturze (TC1, TC2), Wyzwolenie zwierząt (SWy), W obronie zwierzat (SW), Dekonstrukcja antropocentryzmu w monodramie Koniec półświni Helmuta Kajzara (SD), Autoteliczni nie-ludzie (KA), Filozoficzne podstawy praw zwierzat (PF), Rozmowy z psem, czyli komunikacja międzygatunkowa (AR), Człowiek $w$ świecie zwierząt - zwierzęta w świecie człowieka (IC), Poświatowska posthumanistyczna? (PP), Zarys prawa $w$ odniesieniu do sztucznych inteligencji i osób emulowanych (MZ), Zjadanie zwierząt (FZ), Wieczne życie. O zwierzęcej formie śmierci (HW), Śmierć zwierzęcia. Współczesne zootanatologie (KŚ), Farba znaczy krew (KF).

Te kilkanaście egzemplifikacji przekonuje nas o dużym stopniu komunikatywności tytułów tekstów dyskursu posthumanizmu. Można stwierdzić, że tytuły te pełnią przede wszystkim dwie z przyjętych w literaturze naukowej funkcji nagłówków (Pisarek 1967; Gajda 1987; Żydek-Bednarczuk 2005: 170-180). Są to: funkcja nominatywna i deskryptywna, a najczęściej połączenie ich obu. Funkcja nominatywna ,wiąże się z onimiczną funkcją tytułu i polega na indywidualnym nadaniu «nazwy» tekstowi. Funkcja nominatywna bywa połączona $\mathrm{z}$ funkcją deskryptywną" (Żydek-Bednarczuk 2005: 172). Nieco szerszy jest zasięg funkcji deskryptywnej, uważanej za „charakteryzującą i informującą o zawartości tekstu [...]. Tekst nie tylko nazywa, ale również opisuje, charakteryzuje i informuje" (Żydek-Bednarczuk 2005: 173). Rzadziej natomiast można mówić w badanym materiale, co widać także w przytoczonych przykładach, o tytułach metaforycznych, wieloznacznych.

Obszar dyskursu posthumanizmu określa również właściwa dla niego terminologia, np.:

${ }^{4}$ Kwestie relatywizmu bliskie są również hermeneutom, z których ustaleń lingwiści korzystają w znaczącym stopniu. Por. Pytlas 2010.

${ }^{5}$ Uwzględnione zostały zarówno teksty polskie, jak i thumaczenia z języków obcych. Zakładam bowiem, że tekst przyswojony zaczyna funkcjonować w danej (w tym wypadku polskiej) rzeczywistości dyskursowej i współtworzy ją. 
posthumanizm, transhumanizm, gatunki stowarzyszone - traktowane na równi organizmy żywe, głównie człowiek i zwierzęta przez niego oswojone (np. psy),

zwierze nie-ludzkie/nie-człowiek - przedstawiciel gatunku zwierząt innego niż człowiek,

antropomorfizacja zwierzat,

gatunkowizm - antropocentryzm, traktowanie człowieka jako gatunku nadrzędnego, panującego,

antygatunkowizm/postgatunkowizm - uznanie wszystkich organizmów zwierzęcych, w tym człowieka, za równouprawnione,

postantropocentryzm, postindywidualizm, genderyzacja i seksualizacja mięsa przypisanie ciału zwierzęcemu cech tradycyjnie odnoszonych do ciała człowieka,

sprawstwo - zdolność do działania jako wynik pragnienia, intencji i decyzji, przypisywane także innym niż człowiek bytom (np. zwierzętom, robotom),

zoe-filia - empatia, przyjaźń w stosunku do zwierząt,

zoe-polityka - polityka na rzecz zwierząt,

bioart/sztuka postgatunkowizmu - sztuka podejmująca problematykę relacji człowieka do nie-ludzkich form życia,

posthumanistyka - refleksja, głównie filozoficzna, nad różnymi aspektami nie-ludzi,

życie abiotyczne - szerokie rozumienie życia wyrażające się w relacji człowieka do rzeczy i cyborgów.

Przywołane egzemplifikacje uzmysławiają, że dyskurs posthumanizmu opiera się przede wszystkim na odcięciu się od ustaleń wcześniejszych, uogólniając antropocentrycznych. Świadczy o tym na przykład duża frekwencja prefiksu posttworzącego leksykę specjalną dyskursu. Terminologia koncentruje się wokół nowych podmiotowości oraz szeregu przypisywanych im cech, właściwości i znamion, przede wszystkim natury kulturowo-społecznej.

Prócz leksyki specjalnej, właściwej w głównej mierze dla tekstów reprezentujących styl naukowy i popularnonaukowy, rzadziej publicystyczny, w dyskursie posthumanizmu pojawiają się szeroko pojęte neosemantyzmy i neologizmy, zazwyczaj w formie struktur nieciągłych:

eksploatacja zwierząt - wykorzystywanie zwierząt w celu czerpania korzyści przez człowieka,

komunikacja międzygatunkowa - porozumiewanie się człowieka z bytami nie -ludzkimi,

\footnotetext{
${ }^{6}$ Taki zapis z partykułą przeczącą nie został przyjęty również w niniejszym opracowaniu.
} 
niekończąca się Treblinka - masowe mordowanie zwierząt w rzeźniach,

etyka maszyn - refleksja dotycząca kwestii etycznych bytów nieludzkich stworzonych przez człowieka,

antropocentryczne urządzenie - maszyna pełniąca funkcję/imitująca człowieka (np. robot, cyborg),

żywe rzutki - o ptakach jako celu myśliwych,

zwierzęce emocje,

umieranie/odchodzenie zwierzęcia - zamiast: 'zdychanie'.

Podobne połączenia wyrazowe, niepełniące funkcji terminu bądź pełniące ją wybiórczo, kontekstowo, pojawiają się w badanym dyskursie w różnym natężeniu. Jedne z tych jednostek zdają się uprawomocnione, uogólnione, stosowane przez różnych autorów, inne zaś noszą znamiona realizacji jednostkowych, nierzadko kreatywnych i metaforycznych.

Jak już wspomniałem, wykładnikiem dyskursu posthumanizmu jest przede wszystkim temat, ale również funkcja polegająca na przeobrażeniach tradycyjnego sposobu postrzegania bytów nie-ludzkich zmierzających między innymi do nadania im cech podmiotowości i tym samym poszerzenia perspektywy refleksji, w nowym kształcie - posthumanistycznej. Wymiar pragmatyczny dyskursu jest aktualizowany za pomocą różnych środków. Jednym z nich jest pytanie:

Maszyny liczące popełniają mniej błędów niż ludzie oraz mogą o wiele lepiej i rzetelniej dokonywać obliczeń. Może więc rozum przestał być wyróżnikiem człowieka? (DO, 95)

Czy maszyny mogą odczuwać cierpienie? Czy w ogóle mogą odczuwać jakiekolwiek emocje? Czy doświadczają tego typu stanów? (DO, 99)

Czy w ogóle są nam potrzebne dowody z zakresu nauk biologicznych pokazujące podobieństwa zwierząt do człowieka, aby dokonał się zasadniczy przełom w podejściu do zwierząt? (SC, 25)

Psy są wspaniałe i pod wieloma względami wyjątkowe. I bardzo mądre. Świnie też są mądre i też czują. Nie potrafią wprawdzie wskakiwać do bagażnika, ale potrafią aportować, bawić się, psocić i odwzajemniać uczucia. Dlaczego więc zamiast karmić je pieczenią, nadziewamy je na ruszt? $(\mathrm{FZ}, 24)$

Dlaczego zatem, pomimo najnowszych danych z zakresu neurobiologii i etologii, istnieje powszechna tendencja do lekceważenia cech wspólnych, biologicznie łączących ludzi i zwierzęta? (PF, 195)

Jakie konsekwencje niesie ze sobą fakt, że technologiczne urządzenie (apparatus) nie jest już upłciowione, urasowione czy znaturalizowane, ale raczej neutralizowane w figurach zmieszania, hybrydyczności i wzajemnego powiązania, co czyni z transseksualności dominujący posthumanistyczny topos? Jeśli maszyna jest zarazem samoorga- 
nizująca się i transgenderowa, to gdzie mamy szukać starego organicznego ciała ludzkiego? (BP, 199)

Abstrahując od dyskursu posthumanizmu, można wskazać różne funkcje struktur pytajnych. Pośród nich dominuje dynamizująca, czyniąca z tych konstrukcji pytajne kwalifikatory tekstu (Boniecka 2000: 53-77), częste w wypadku stylu naukowego, który pewna grupa z powyższych przykładów reprezentuje. Można wówczas mówić o pytaniu jako wykładniku struktury przyczynowo-skutkowej wywodu, przeprowadzającym odbiorcę przez tok rozumowania nadawcy. Nierzadkie, co potwierdzają egzemplifikacje, są również pytania retoryczne, ich stosowanie ,polega na zamierzonym «wyciszeniu» wolitywnego składnika struktury pytania prowadzącym do degradacji pytania jako pytania" (Boniecka 2000: 213). Zarówno dynamizowanie wywodu, jego porządkowanie, jak i niwelowanie prototypowej cechy struktur pytajnych przez zamierzoną rezygnację z odpowiedzi stanowią o specyfice pytań stosowanych w dyskursie posthumanizmu. Celem jest bowiem sprowokowanie do namysłu nad tradycyjnym porządkiem świata, a następnie zweryfikowanie stereotypowych o nim wyobrażeń.

Dyskusja z zastanym, antropocentrycznym kształtem rzeczywistości polega także na zestawianiu cech, wykładników obu światów - humanistycznego i posthumanistycznego. Oto przykłady:

Ludzki mózg wykształcił wyspecjalizowane mechanizmy nerwowe do wizualnego rozpoznawania twarzy, które dają nam niezwykłą zdolność rozróżniania, pamiętania i myślenia o wielu setkach różnych osób. Owce także rozpoznają inne owce oraz ludzkie twarze, ponieważ posiadają w płatach skroniowych i czołowych podobne wyspecjalizowane systemy nerwowe, które umożliwiają im realizację tego społecznego zadania. (SC, 25)

Każde zwierzę jest nagie - nagie w obliczu człowieka, nagie, gdy wystawione jest na wzrok, obserwację, wpatrywanie się, niewinne i zarazem nieświadome swej nagości. $(\mathrm{KC}, 39)$

Gęsi żyją do piętnastu lat w monogamicznych parach. Gdy jedno z pary zginie - drugie najczęściej do końca życia pozostaje samo. Wędrują w rodzinnych stadach składających się z rodziców i dzieci, dalszych krewnych, a nawet dalekich kuzynów i powinowatych. Ich stadny behawior i wzajemne powiązania rodzinne są dobrze opisane przez laureata nagrody Nobla, Konrada Lorentza. (KP, 24)

Interesują go [Eduarda Kaca - A.R.] bowiem związki między rozmaitymi formami życia, a w szczególności, jak twierdzi, między umysłami ludzkimi i zwierzęcymi. Życie zaś nie ogranicza się do kodu DNA, który to w istocie można wyizolować i zmanipulować, jednak życie w całej swojej złożoności nie może przetrwać w izolacji. Tak więc dzięki pozaludzkim formom życia, w tym wypadku dzięki zwierzętom, dowiadujemy się też czegoś o sobie i o naszych relacjach z nimi. (BS, 115-116) 
Można by, trywializując problem, mówić tutaj o antropomorfizacji bytów nie -ludzkich, ich aspirowaniu do świata człowieka. Istotą dyskursu posthumanizmu jest jednak chęć wskazania cech wspólnych różnych gatunków i fenomenów transhumanistycznych oraz przekonanie o zasadności równego ich traktowania. Rozpoznawanie twarzy przez owce, monogamiczny charakter związków gęsi, paralele między ludzkimi i zwierzęcymi umysłami czy przypisanie zwierzętom cechy bycia nagim - to właściwości, często potwierdzone naukowo, ale też zaobserwowane na skutek codziennego obcowania człowieka z innymi gatunkami, zmierzające do popularyzacji założeń dyskursu posthumanizmu, wprowadzenia ich w szerszy obieg społeczny.

Aktualizacja idei posthumanizmu znajduje również wyraz w ich dyskursywizowaniu w postaci wyróżnionych ogniw tekstowych przywodzących na myśl cechy komunikacji oficjalnej:

Co powiedziałyby nam i o co zapytałyby nas zwierzęta, gdyby potrafiły mówić ludzkim językiem? Oto z czego, jak wierzę, składałby się ich manifest:

1. Wszystkie zwierzęta dzielą Ziemię i musimy koegzystować.

2. Zwierzęta myślą i czują.

3. Zwierzęta mają i zasługują na współczucie.

4. Więzy mnożą troskę, alienacja brak szacunku.

5. Nasz świat nie jest miłosierny dla zwierząt.

6. Miłosierne zachowanie pomaga wszystkim istotom i naszemu światu. (BM, 16)

(...) trzy prawa Isaaca Asimova:

1. Robot nie powinien skrzywdzić człowieka ani przez brak działania pozwolić mu na zrobienie sobie krzywdy.

2. Robot musi słuchać rozkazów wydawanych mu przez człowieka, poza tymi, które są sprzeczne z pierwszym prawem.

3. Robot musi chronić siebie tak długo, jak długo nie koliduje to z pierwszym i drugim prawem. (DO, 96)

Precyzja, komunikatywność, standaryzacja, formuliczność, petryfikacja, czy wreszcie paralelizm struktur składniowych, a także schematyzm ogniw tekstowych sformułowanych w postaci rejestru - to wyznaczniki i cechy komunikacji oficjalnej, przede wszystkim urzędowej. Formułowanie podobnych wypowiedzi legitymizuje dyskurs posthumanizmu, nadaje mu cechy równoprawne wobec innych aktualizacji komunikacji oficjalnej, znowu zatem można mówić o zniesieniu dominacji antropocentrycznego porządku świata.

***

Przedstawione obserwacje, noszące znamiona zaledwie rozpoznania problemu, pozwalają już jednak sformułować kilka wniosków dotyczących dyskursu posthumanizmu: 
Należałoby uznać dyskurs posthumanizmu za przykład dyskursu ideologicznego, jego założenia bowiem oparte są na dążeniu do zmiany postrzegania porządku zastanego, zmierzają do uznania odmiennej od zwyczajowo przyjętej hierarchii wartości.

Tematyka jest w wypadku tego dyskursu kluczowa, o czym świadczy wyraźne jej sygnalizowanie w tytułach tekstów aktualizujących dyskurs, a także jej uniwersalność niezależnie od stylu czy gatunku.

Obserwuje się wyrazistą specyfikację dyskursu manifestującą się w tworzonej leksyce specjalnej i neosemantycznych połączeniach wyrazowych.

Dyskurs posthumanizmu charakteryzuje się dużą dynamiką, wyrażaną na przykład za sprawą używanych struktur pytajnych, często o charakterze retorycznym, pełniących funkcję perswazyjną.

Punktem odniesienia dla dyskursu posthumanizmu jest tradycyjny - antropocentryczny - porządek rzeczywistości, co poświadcza specyficzny obraz świata akcentujący równość wszelkich gatunków żywych i bytów transhumanistycznych polegającą na przypisywaniu im i dowodzeniu cech stereotypowo uznanych za ludzkie; wynika to z faktu, że dyskurs funkcjonuje w obszarze komunikacji człowieka.

Dyskurs posthumanizmu wzbogaca współczesną przestrzeń komunikacyjną, w znacznym stopniu poszerza kategorię podmiotu i tym samym reinterpretuje pojęcie kultury komunikacji.

\section{Rozwiązanie skrótów wykorzystanych źródeł}

AR - Antas J., 2014, Rozmowy z psem, czyli komunikacja międzygatunkowa, Warszawa. BM - Bekoff M., 2014, Manifest zwierząt, w: KŚS.

BP - Braidotti R., 2014, Po człowieku, przekł. J. Bednarek, A. Kowalczyk, przedmowa J. Bednarek, Warszawa.

BS - Bakke M., 2012, Sztuka współczesna w trosce o zwierzęta, w: IC.

DO - Dzwonkowska D., 2014, Od antropocentryzmu do ontocentryzmu - współczesne propozycje dyskursu praw bytów pozaludzkich, w: TC1.

FZ - Foer J.S., 2013, Zjadanie zwierząt, przekł. D. Dymińska, Warszawa (ebook).

GP - Grazia de D., 2014, Prawa zwierząt. Bardzo krótkie wprowadzenie, przeł. P. Polak, Kraków.

HM- Haraway D., 2003: Manifest cyborgów, przeł. S. Królak, E. Majewska, „Przegląd Filozoficzno-Literacki”, nr 1, s. 49-87.

HW- Heinrich B., 2014, Wieczne życie. O zwierzęcej formie śmierci, przeł M. Szczubiałka, Wołowiec (ebook).

IC - Ilski K., red., 2012, Człowiek w świecie zwierząt-zwierzęta w świecie człowieka. Poznań.

KA - Kasprzak M., 2014, Autoteliczni nie-ludzie, w: TC2.

KC - Kotyczka M., 2014, Cierpienie gatunku, w: KŚ.

KF - Kruczyński Z., 2008, Farba znaczy krew, przedmowa O. Tokarczuk, Gdańsk (ebook).

KP - Kruczyński Z., 2014, Piękne, wolne, ginące, w: KŚ. 
KŚ - Kotyczka M., red., 2014, Śmierć zwierzęcia. Współczesne zootanatologie, Katowice.

MZ - Muzyka K., 2014, Zarys prawa w odniesieniu do sztucznych inteligencji i osób emulowanych, w: TC2.

PF - Probucka D., 2013, Filozoficzne podstawy idei praw zwierząt, Kraków.

PP - Pietruszewska-Kobiela G., 2014, Poświatowska posthumanistyczna?, w: TC2.

SC - Skubała P., 2014, Czy odkrycia nauk biologicznych moga zmienić nasz stosunek do zwierzat?, w: TC1.

SD - Szumlas K., 2014, Dekonstrukcja antropocentryzmu w monodramie Koniec półświni Helmuta Kajzara, w: TC1.

SW - Singer P., red., 2011, W obronie zwierzat, przeł. M. Betley, Warszawa.

SWy - Singer P., 2004, Wyzwolenie zwierząt, przeł. A. Alichniewicz, A. Szczęsna, Warszawa.

TC1 - Tymieniecka-Suchanek J., red, 2014, Człowiek $w$ relacji do zwierząt, roślin i maszyn w kulturze, t. 1: Aspekt posthumanistyczny i transhumanistyczny, Katowice.

TC2 - Tymieniecka-Suchanek J., red, 2014, Człowiek $w$ relacji do zwierząt, roślin i maszyn w kulturze, t. 2: Od humanizmu do posthumanizmu, Katowice.

\section{Bibliografia}

Boniecka B., 2000, Struktura i funkcje pytań w języku polskim, Lublin.

Derra A., 2010, Czy wielość prowadzi do dowolności. O użytecznym wymiarze relatywizmu, w: Relatywizm w języku i kulturze, red. A. Pajdzińska, R. Tokarski, Lublin, s. 11-24.

Dijk van, T.A., red., 2001, Dyskurs jako struktura i proces, przeł. G. Grochowski, Warszawa.

Gajda S., 1987, Społeczne determinanty nazw własnych (tytułów), „Socjolingwistyka”, nr 6, s. 79-89.

Grzmil-Tylutki H., 2007, Gatunek w świetle francuskiej teorii dyskursu, Kraków.

Krzeszowski T., 1999, Aksjologiczne aspekty semantyki językowej, Toruń.

Labocha J., 2008, Tekst, wypowiedź, dyskurs w procesie komunikacji językowej, Kraków.

Pisarek W., 1967, Poznać prasę po nagłówkach. Nagłówek wypowiedzi prasowej w oświetleniu lingwistycznym, Kraków.

Pytlas M., 2010, Paninterpretacjonizm - czy hermeneutycy mówia prawdę?, w: Relatywizm w języku i kulturze, red. A. Pajdzińska, R. Tokarski, Lublin, s. 85-94.

Tymieniecka-Suchanek J., 2014, Stowo wstepne, w: Człowiek w relacji do zwierząt, roślin i maszyn w kulturze, red. J. Tymieniecka-Suchanek, t. 1: Aspekt posthumanistyczny i transhumanistyczny, Katowice, s. 9-13.

Witosz B., 2009, Dyskurs i stylistyka, Katowice.

Witosz B., red., w druku, Dyskurs i jego odmiany, Katowice.

Wojtak M., 2011, O relacjach dyskursu, stylu, gatunku i tekstu, „Tekst i Dyskurs - Text und Diskurs", nr 4, s. 69-78.

Żydek-Bednarczuk U., 2005, Wprowadzenie do lingwistycznej analizy tekstu, Kraków. 